\title{
COSMOPOLITAN MALAY THROUGH VISUAL IMAGERIES IN 1930S MALAY NEWSPAPERS
}

\author{
Razan Rosman* \& Sarena Abdullah** \\ ( ${ }^{*}$ First author, ${ }^{* *}$ Corresponding author) \\ School of the Arts, Universiti Sains Malaysia \\ (razanrose92@gmail.com, sarena.abdullah@usm.my) \\ Doi: https://doi.org/10.22452/ jati.sp2018no1.9
}

\begin{abstract}
By 1930s, Malays specifically the city dwellers have already grown accustomed to the modern lifestyle, espoused by their cosmopolitan appearance and outlook. The period portrays an increase of leisure and recreational activities particularly in the consumption of goods, services, and popular entertainment-reflected in the abundance of advertisements on this type of products and activities in Malay newspapers. By late 1930s, advertisements mostly published in the form of visual imageries. Analysis on these imageries can provide insights on the presence of a certain form of cosmopolitanism embodied by this group of urban Malays. This exploratory paper inspects the portrayal of cosmopolitan Malays through visual advertisements in Warta Ahad in the second half of 1930s (1935-38). Archived materials mentioned in the paper were gathered from Perpustakaan Tun Sri Lanang, Universiti Kebangsaan Malaysia (UKM). The conception of Malay cosmopolites, as this paper will argue, is a construct by advertisers and Malay intelligentsias alike, albeit with different intentions. Imageries under discussion suggest an alternative representation of Malays, the urbanites, who have attained a degree of cosmopolitan outlook through continuous exposures to what was deemed as a modern lifestyle.
\end{abstract}

Keywords: Malay newspapers, urban Malays, advertisements, cosmopolitanism, modern lifestyle 


\section{Introduction}

The 1930s, often perceived as the interwar period between established and rising empires, held much wider narrative within it. The tumultuous decade offers narratives-despite prevalent and rising nationalisms especially amongst colonies of empires - characterised by a wider global context i.e. development of internationalist impulses and transnational connections (Matera \& Kent, 2017). Increasing interconnectivity, mainly due to the expansion of production and distribution driven by imperial conquests, had enabled a large import of goods and services to third world nations or colonies of empires. This also meant the import of cultural products, from export nations such as America, contributing to the growing consumption culture amongst these nations to-be. This can be observed in the modern, urban settings of Malaya that were first established in port-cities such as Penang and Singapore. These two cities, which thrived in late nineteenth century, became centres for colonial administration, trade and commerce, as well as hubs for knowledge, ideas, and cultures. This later led to the establishment of a polyglot society, contributing to a significant increase in numbers of the urban population (Sivachandralingam Sundara Raja, 2014).

Penang and Singapore have thriving printing and publishing as well as entertainment industries by 1930s. There is a symbiotic relationship between the two industries, reflected in newspaper publications-in this case, Malay newspapers. Such condition can be read in the larger context pertaining to the transitional phase in terms of Malay education after British's forward move in 1874 (Khoo Kay Kim, 1974). These vernacular and English graduates later went on to become teachers and journalists, the early Malay autochthonous intelligentsias (Roff, 1967), who have firm grasp on nuances of the modern setting. They can be regarded as cosmopolites in a way that they perceived the world differently from their rural counterparts. Their awareness on the interconnected world is thus reflected in their familiarity with the modern framework e.g. notion of development, social organisation, capitalistic wealth accumulation, political associations, and identity formation.

Our observation on Wak Ketok column in Utusan Zaman-specifically his critiques on the so-called urban Malays-finds that these Malay cosmopolites were portrayed as having different attitude and outlook as compared to their rural counterpart; amongst others, the prioritisation of individual gain and hedonistic lifestyle (Razan Rosman \& Sarena Abdullah, 2018). Malay newspapers at the time gained considerable influence amongst the people due to their prominent role as the sole medium for disseminating information. We locate the cosmopolitan condition and outlook in the reflection of critiques on this category 
of Malay as a counter projection to advertisements published in Warta Ahad that portrays a type of localised leisure culture derived through consumption of goods associated with particular Malay pastime activities.

Studies on the development of Malay periodicals - in this context, prewar Malay newspapers - revolves around the documentation of publications, especially for early periodicals. The documentation provides useful information on the numbers of Malay periodicals published in a specific period (Roff, 1961; Hamedi Mohd. Adnan, 2015) where, amongst others, could reflect the level of participation of Malays in printing and publishing industry. Studies on Malay newspapers, specifically, often rest its focus on the role of pre-independence Malay newspapers as a medium and/or catalyst for the growing Malay political consciousness, or Malay nationalism. This also includes periodisation of newspapers according to dominant discourse in each of the period (Nik Ahmad Haji Nik Hassan, 1963) and historical analysis on published writings in relation to their socio-political context (Roff, 1967); while contemporary works of documentation of these periodicals would provide updates on latest publications as well as corrected fact and reviews on previous works (Hamedi Mohd. Adnan, 2015). Ahmat Adam (1992) who observes the development of Malay newspapers in the region indicates the presence of a close interrelated relations between Indonesia and Malaya at that time where newspapers from both places took news from each other's location for local consumption. This, in a way, displays a form of 'awareness' between the two places with each other, as well as active process of exchange of ideas.

Development of Malay newspapers vis-à-vis Malay political consciousness and nationalism in pre-war Malaya tend to focus on writings and articles filled mostly pertaining to Malay socio-political standings against the backdrop of developing colonial territories. In this case, there were dialogues, and discourses presupposed by specific ideas and notions of the Malay, advocated by different strands of Malay intelligentsias. This, however, only provides one side of observation where these writings, as with all of writings, were sometimes intentionally distortive in nature where some aspects of Malay society, especially urban Malays, were concealed and some others were generalised. In this sense, observation on visual imageries in pre-war Malay newspapers attempts to provide a balanced portrayal of the urban Malays at that time.

In terms of visuals, Muliyadi Mahamood's (2004) seminal work, The History of Malay Editorial Cartoons (1930s-1993), remains comprehensive documentation of Malay editorial cartoons. According to him, "Malay editorial cartoons have played an important part in the cultural and political development 
of the Malays" (Muliyadi Mahamood, 2004, p. 1) where newspapers such as Utusan Zaman played an important role in the "development of the style and critical humour of Malay editorial cartoons" (Muliyadi Mahamood, 2004, p. 2). Editorial cartoons, while providing immediate response to current issues, also, whether implicit or explicit, portray certain traits and characteristics sourced from the actual, everyday life of the subject that could not simply be dismissed. Rather than a long exhortative articles, cartoon has a dynamic of visuals and text, in which both may be representing a same critique but nevertheless could also display contradictory relationship between visuals and text. In so doing, observation on visual imageries and illustrations would enable a better and comprehensive understanding on the Malay society in the 1930s beyond the writings of Malay intellectuals who have the tendency to overgeneralise the impoverished social condition of Malays at that time. It gives insight on what could seemingly be a fairer observation on the condition of urban Malays through the portrayal of habits, behaviours, and characteristics despite the cartoons itself were meant to be a critique.

This paper explores the representation of the cosmopolitan Malays in urban setting as portrayed by visual imageries in Warta Ahad's advertisements with reference to critique on this group of Malays by Utusan Zaman's Wak Ketok in late 1930s. The first part will provide a brief overview of the development of Malay newspapers since 1876 to 1930s, particularly on the development of style in advertising as well as the increasing reliance on pictorial contents. The second part includes the cosmopolitanism framework where we try to frame the qualities of what we call Malay cosmopolites against the cosmopolitan setting of port city. Lastly, this article identifies the process or emergence of these cosmopolitan Malays, represented in advertisements on leisure activities as well as critiques in Wak Ketok series. While both elements, advertisements and caricature, differed in terms of their intentionality, nevertheless they functioned as agent that constructed the image of Malay cosmopolites-through portrayals of imageries containing a degree of ideological intervention. That said, this representation of Malay cosmopolites offers an alternative perspective of a segment of Malay society who seemed to contradict the mainstream Malay nationalist discourse promoted at that time. They fit into the notion of progress brought by modernity, yet they did not seem to identify themselves with either strands of Malay (cultural) or Islamist (reformist) nationalism; their allegiances, so to speak, was situational depending on the context in which they were in made possible by exposures to different kinds of ideas, cultures, and outlooks, all that turned them into cosmopolites. 


\section{The 1930s Malay Newspapers}

The tradition of Malay journalism is marked by the publication of the Jawi Peranakan in Singapore, 1876. Pre-war Malay newspapers, as Nik Ahmad Haji Nik Hassan (1963) observes, could be categorised into three phases; each phase was characterised by its predominant discourse portrayed in the pages of newspapers of the era. It also indicates a gradual shift of thinking and attitude amongst pre-war Malay intelligentsias from their concern on the correct usage of Malay language towards a more political posture revolving around the Malay socio-political and economic concerns (Nik Ahmad Haji Nik Hassan, 1963; Roff, 1967). It was within the decade of 1930s leading to World War 2 (WW2) that we could observe an increasing and active participation of non-elite Malay intelligentsias - many of them came from Malay vernacular schools and religious schools like pondok or madrasah - in contesting and negotiating their versions of an 'imagined Malay identity' particularly against the urban, modern, and cosmopolitan backdrop of Penang and Singapore.

The early Malay printing and publishing industry reached its peak in the 1930s despite the Great Depression. While the slump had caused the world economy to contract and affected various economic sectors, the "publishing and popular entertainment industries" had not only managed to survive but also thrived successfully (van der Putten, 2010). This is partly contributed by the rise of American popular culture as well as the strategic changes made by media moguls such as reducing the prices of entertainment (van der Putten, 2010). For the publishing industry, the decade saw the publication of 81 Malay periodicals in various states in Malaya including Federated and Unfederated Malay states such as Kelantan, Negeri Sembilan, and Perak (Roff, 1967, p. 166). According to Roff (1967, p. 166):

The chief characteristic of this vigorous activity was perhaps the increasing commercialisation and professionalism of journalistic enterprise in response to a growing audience for cheaply priced popular reading matter. To those who earlier had started newspapers or journals for ideological reasons, or as a by-product of associational activity, were added the Malay (or more often, the Malayo-Muslim) businessmen who saw in the periodical publication a potential source of return on capital. Monthly, fortnightly, and weekly magazines were produced to provide light entertainment for the generality of Malays and to cater to the special interests of such groups as young people, women, and 
children. Illustrated journals made their appearance, and magazines devoted wholly or mainly to locally written short stories or humorous material.

Roff's observation captures the overall feature of Malay newspapers of the period. In late 1930s, a number of Malay youths such as A. Samad Ismail and Ibrahim Yaacob, both were inspired by writings of Abdul Rahim Kajai and Ishak Haji Muhammad joined the publishing industry as journalists (A. Samad Ismail, 1993). These were the young Malays who later assumed prominent roles as political activists and journalists in the period of post-WW2 up until postIndependence era. Established journalists like Kajai also received a high salary, signifying how lucrative the publishing business was during the time. One of the factors was the growing numbers of literate Malays as the audience for these publications as well as the cheap price of periodicals due to technological advancement that reduced printing time and cost.

Two notable features of the 1930s Malay newspapers are its structure and content. The latter is largely marked by the growth of newspapers as a site for discussion amongst Malays. As observed by Mark Emmanuel (2010), Malay newspapers at the time were increasingly becoming a kind of "viewspaper" filled with "opinions, commentaries, leading articles and editorials rather than news". Almost all of the articles and commentaries portray strong racial awareness especially with regards to Malays' economic backwardness vis-à-vis Chinese immigrants as well as Arab and Indian (-Muslim) merchants. On the one hand, the demographic factor that saw a great influx of immigrants, especially the Chinese, due to British's immigration policy along with the increasing demands made by the immigrants for their political rights had incited the Malay's sense of vulnerability (Emmanuel, 2010; Lewis, 2009). On the other hand, the economic downturn caused by the Great Depression had greatly increased the insecurity of Malays regarding their deprived and impoverished economic condition-viewed in comparison with other ethnics especially the Chinese (Emmanuel, 2010). The rise of Malay nationalism in the post-war period owed a great debt to the establishment of Malay printing and publishing industry in the 1930s. The period also provided the foundation that shaped the Malay discourse revolving around socioeconomic backwardness, special political and economic protection as the native of the land, as well as their inclusion in the government administration.

The second feature is the structure and design of Malay newspapers. By early 1930s, many Malay newspapers started to adopt neater designs with clear subheadings and covered more topics including sports, local and foreign affairs, 
as well as film reviews. The expansion of columns including news reports on sports activities such as football or badminton as well as boy/girl scouts reflects the already established consumption of recreational activities amongst Malays in the era. Roff (1967) observes a growing number of Malay social and sports clubs to cater to the growing interest and participation in these leisure activities. The social clubs were modelled from elite European clubs in Malaya that offered limited access-only for Europeans and a very small number of non-Europeans residing in Singapore. By this time, sports and youth activities have been included as co-curriculum in many Malay vernacular schools. Malay newspapers covered annual jamborees, inter-school badminton or football tournaments on a regular basis. The form of coverage, as it had become common during that time, were often in pictorial form with short captions.

The feature of 1930s Malay newspapers saw a significant increase in illustrative content including caricatures, photographs, and illustrated advertisements. The design became dependent on pictorial content made accessible by the cheap price of cameras, enabling a commercial use of photography. Newspapers such as Warta Malaya (1930-41) and Utusan Melayu (1939-42) published weekly newspapers, Warta Ahad (1936-41) and Warta Jenaka (1936-41), as well as Utusan Zaman (1939-42) and Mastika (1941-42) respectively as light readings for their audience. The weeklies provided humour and entertainment to their readers in the form of caricatures, photos, short stories, traditional poetries (such as gurindam, syair, pantun, seloka) along with interesting articles and advice that were useful to the Malays (Hamedi Mohd. Adnan, 2015, p. 87, 99-101). They adopted an illustrative approach and published more photographs on global and local affairs, as well as catchy and targeted illustrated advertisements. Weeklies such as Warta Ahad tended to dedicate four to six pages (starting from the centre pages) for pictorial content, from photographs of war to visits to local schools and madrasah.

\section{Cosmopolitanism, Port Cities, and Malay Cosmopolites}

Port cities of Penang and Singapore-as urban centres and colonial administration centres-relied heavily on the vital role of newspapers in mediating messages beyond the government-public communication; it was also a medium and a point of intersection between various segments of the society. As main hubs and centres for the region, port cities were the first territory to receive new technologies, trends, as well as high exposure on the global networks. The setting allowed societies in port cities to develop a cosmopolitan character in terms of the exposure to the global framework-similarities, distinctions, 
interconnectedness-and the awareness on the existence of a universal community where everyone shares a certain set of values despite cultural differences. Within this cosmopolitan setting, residents in port cities in Malaya gradually equipped themselves with the language and tools to negotiate the differing values, norms, and ideals -integrating and excluding external elements and influences through adaptation, negotiation, and incorporation of these elements as their own.

In the context of Penang, as Su Lin Lewis (2009) noted, the "networks of trade and immigration" not only had an effect on the locals' economic mode of production, but can also be observed in the cultural aspect in which each community negotiated the influence of other local communities and the global influences such as in fashion on their cultural traditions. These negotiations took place-and can be observed-in the pages of newspapers, reflected in discussion on global influence-e.g. the fashion trend amongst younger generations-on their cultural traditions (and identities). Diaspora communities, as observed by Lewis (2009) in Straits Echo, raised their concerns through opinions and debates in commentary and letter to editor slots provided by the newspaper. One of their many concerns centred on the preservation of their cultural identity vis-à-vis waves of foreign influences catalysed by the influx of goods and services imports including the global entertainment culture.

Penang's polyglot society, mirroring Singapore's composition, was, borrowing Lewis' phrase, a "tangled web of solidarities" in which the notion of identity-at least those portrayed by the younger generations of that era-was conditioned by the many affiliations espoused by these various segments and communities (Lewis, 2009). Such political and cultural allegiances was a result of the cosmopolitan setting experienced by locals in these two port cities, giving birth to a kind of 'double consciousness', meaning that:

[C]osmopolitanism as a consciousness of belonging to a larger, global world above and beyond that of a particular community or nation-state, one made possible through the experience of modernity, which rendered the world at once larger (in complexity), smaller (in connectedness) and more universally comprehensible through the spread of modern education, printculture, cinema and technology. At the same time, cosmopolitanism is also a consciousness of living in a particular multicultural society, in which individuals draw upon and reshape their own group traditions through cross-cultural dialogue in a dynamic public sphere. (Lewis, 2009) 
The dual (or multiple) identities conceived by the locals reflect a conflicting yet rather harmonious amalgamation of perceptions and practices of cultural traditions in relations to the modern framework of port cities. These different set of ideas or beliefs were unintentionally promulgated or consciously advocated through publicities, in terms of utilising the communicative medium, particularly newspapers, to effectively influence the public. It is arguably true that the subject matters, with regards to Malay newspapers of the era, proposed a rather generalised and 'imagined' observation on Malay community in generalwith little or any regard to factors such as demography in specific location. Nevertheless, such commentaries and critiques of the Malay community itself would not be possible without the existence of a setting that transcended the Malay cultural (and feudal) sphere as an actual source for critical observations and comparative assessments. Again, we look into Lewis' (2009) observation on the image of the Modern Girl showing that the locals in Penang, at least the younger generations, have already acquired a global taste reflected in their fashion taste and appearance. This also came with the adoption of a cosmopolitan idea, which later developed into a larger understanding and solidarity with the world-identification as a citizen of the global communitythat is not limited to one's rigid sense of cultural root, nor did it is limited to one's nationalist tendency.

Thus, cosmopolitanism in Penang, and in this particular context, Singapore, in which the modern, urban setting had subtly stipulated its society to adapt to was expressed, albeit indirectly, within the pages of Malay newspapers itself - through the portrayal of these type of Malays in leisure and entertainment advertisements as well as critiques by Malay intelligentsias. For the latter, such as the case for Kajai, the critiques and the imagination of the 'ideal Malays' was primarily sourced from his surroundings, i.e. Singapore. For Malays, the cosmopolitan portrayal came in both advertisements and critiques, which includes the element of intra-ethnic contestation where the envisioned Malay ideals advocated by Malay intelligentsias materialised through internal distinction with the other Malays (Johnson, 2006), which in this context, refers to Arab and Jawi Peranakan, as well as the urban, cosmopolitan Malays. In hindsight, it also portrays the presence of agency on the side of Malay intelligentsias, who, in their critiques, refused the definition imposed by foreign brands and western media as well as utilising these portrayals-added with their observation on their surroundings - as a source for their critiques.

What we call cosmopolitan Malay or Malay cosmopolite is a portrayal, or an attempt to portray, of a segment of Malay society consisted of urban dwellers 
who possessed qualities distinct to its other counterparts - the rural Malays or Malays residing in Malay states. It is primarily characterised by its locality, i.e. the thriving and urbanising port cities, which entails a different set of values, norms, and ethics as compared to the Malay states. One early comparative assessment between the port city and Malay states can be found in Munshi Abdullah's observation in the first half of $19^{\text {th }}$ century. In his manuscript entitled Kisah Pelayaran Abdullah (The Voyage of Abdullah), he described his journey to Kelantan, located in the East Coast of Peninsula Malaya, also passing by states of Pahang and Terengganu, as a messenger for Sir George Bonham to the Sultan of Kelantan while at the same time acting as interpreter and mediator for an Englishman, Grandpre. Abdullah observes that Malay society in these three states lived in an impoverished condition and possessed bad attitudes i.e. lazy, disorganised, uneducated, and filthy (Abdullah Abdul Kadir, 1838). His most notable observation is a comparison between the Malay kerajaan system with the British colonial system. He argues that the kerajaan system was impending the improvement of Malays in which the people were bound by rigid customs and prohibited from accumulating wealth. People of the Straits Settlements under British rule, on the other hand, enjoyed the protection of law, and were encouraged to improve themselves and accumulate wealth to increase their quality of life (Abdullah Abdul Kadir, 1838). In his words:
When I saw such huge differences between the Malay custom with the English custom, I am forever grateful to be born under the English patronage, for I am able to live in peace, unlike those [under Malay kerajaan rule] who suffer in their ignorance and wickedness. (Abdullah Abdul Kadir, 1838, p. 157/158) (Authors' translation)

Abdullah's critique signifies a certain appreciation towards individualism that
acknowledges the individual freedom to improve one's own intellectual and
material capacity; it is an emphasis on individualism and an egalitarian way of
how society should function. Such remark also indicates the influence of locality
on one's world outlook. Note that he uses the word "custom" (adat in Malay),
denoting that a specific locality - depending on the ruler-would entail a specific
and distinct set of values different from other locality, with establishment of
institutions, networks, and systems, all contributed to the formation of a distinct
culture or "custom". In Abdullah's view, the British colonial system had already
established modern institutions that preserved basic human rights of its people
through maintaining law and order, resulted in a functional system of 
governance which led to a functional society. Abdullah's modern perspective is materialised in his writings which he consciously accepted and practiced the prescribed modern, colonial values. The cosmopolitan setting of port citiesalong with expanding access to education-created a mould for an urban archetype: individuals equipped with an awareness of being in an interconnected world and comprehension of its multiple realities in which these individuals lived in.

What is portrayed by Abdullah Munshi, in his writings, is the double consciousness of a cosmopolite, which a century after, materialised in the form of many common Malay urban dwellers in 1930s Singapore albeit without observational and reflexive acuity such as Abdullah. The cosmopolitan locale of the port city, particularly in its thriving entertainment and leisure industry, created a segment of Malay pejoratively termed by Kajai as the 'sporting spirit' Malays. The term was a stereotype used to characterise Malay urban dwellers who seemed to have been absorbed by the kind of modernity embedded with individualistic attitude, 'Englishmen' aspiration, moral degeneration, living beyond their means, and modernised-reflected in their outlook, appearance, and lifestyle (though this is only what Kajai tried to portray them). They were perceived to have un-Malay-like behaviour and disruptive to the continuation and preservation of 'authentic' Malay cultural tradition. Positioning it this way, these 'sporting spirit' Malays then can be construed as a cosmopolite where, due to their multiple and layered senses of identity, they portray a diverse range of affiliations and identifications towards the variety of attachments in their sociality. Thus, due to this nature, they were considered-by Kajai and 1930s Malay intelligentsias in general-as un-rooted Malays who have forgotten their traditional way of living.

\section{Portrayal of Malays in Advertisements}

The development of Malay newspapers in its early phase is not only seen in its changing content and design, but also the way advertisements were portrayed. Malay newspapers, based on available information, only started to allocate advertisement-related slot in the early decade of 1900s by a newspaper called Cahaya Pulau Pinang (Hamedi Mohd. Adnan, 2015). At that time, what can be construed as advertisement is an extensive elaboration of the advertiser's background and its products. There are a few roughly illustrated advertisements, reserved to international brands such as Nestlé's and Scott's Emulsion, yet with a similar style of elaboration. In the 1930s, however, almost all advertisements, local and international brands, relying on visual imageries with short and catchy 
catchphrases and slogans that specifically addressed their audience. The latter is indicated by the usage of the word "you" that specifically recognises the individual as a potential customer, a subject; and in so doing, also implies a kind of imagination or ideal-in a sense, an ideological one-that the individual would come to be if they consume the product. Advertising, in other words,

...flatters us into thinking we are the special 'you' of its discourse and in so doing we became subjects of and subjected to its material practices: acts of consumption. Advertising is thus ideological both in the way it functions and in the effects it produces. (Storey, 2012, p. 81)

Such understanding would imply that the act of consumption is itself practical and ideological, in a sense that it contributes to the identification of oneself to a certain practice or level of consumption in which social identity would later be represented by types of goods we consume rather than the segments of society we come from. Positing it this way, affiliations (of identities) become varied, and not bound by a single notion of identity-cultural root, religion, race, class (which is also present in multiplicity) - but is situational, located in the context with which the individuals are engaged in, characterised by their behaviours and how they negotiate with the space vis-à-vis their portrayal of identity. This offers us with a tool to observe such situational portrayal. Thus, advertisements, imbued with the intentionality to create the imagination of a certain ideal Malay consumer, in a way, also reflects the presence of such Malay consumers, the cosmopolites, in real life.

While advertisements might not act as an indicator to gauge the level of consumption amongst Malays at that time, their appearance in Malay newspapers itself can be argued to depict the presence of consumption habits amongst urban Malays. Advertising is meant to introduce a product or trend that would later be adopted by the mass public. By targeting Malays, advertisers especially international brands were already aware of the need to expand their market in Malaya as well as the potential of Malay masses to be converted into clients. The interest of brands to advertise in Malay newspapers reflects a kind of recognition on the growing Malay printing and publishing industry possessing a significant number of readership, the potential clients. We argue that the increasing advertisements in Malay newspapers also implies a growing consumption trend, particularly in entertainment and leisure, amongst Malays especially the urbanites. This is observed in the increase of this type of 
advertising campaigns that gradually filled the slots in Malay newspapers. Observation by Jan van der Putten (2010) on Majlis newspaper stated that:

...an increasing number of advertisements informed people about the possibilities for personal entertainment, such as having dinner at a restaurant, watching a movie in a cinema, attending performances by bangsawan troupes or purchasing a new badminton racket at Lall Singh and Company.

van der Putten (2010) also observes that during the time, "readers of Majlis increasingly exposed to products of a modern (elitist) life-style, which included a need for popular entertainment." Published advertisements mainly emphasised entertainment and leisure activities where they informed readers on the latest release of films, music, shows, etc. as well as promoted indulgence in leisure or recreational activities, which reflects the presence of consumption of these activities. Observing this type of advertisement provides insight on the presence of modernity, cosmopolitanism, or both within the specific context of the port city, in this instance, the 1930s Singapore.

In her analysis on lagu Melayu (Malay songs) produced by English-based Gramophone Company (GC), Tan Sooi Beng (2013) argues that there was a form of agency amongst these Malay musicians (of Nusantara) to accommodate the different versions and competing modernities (colonial or vernacular) and Malay nationalisms in which they were infused in a juxtaposed, hybrid music that was not Malay nor Anglo-American but a combination of both. This includes incorporation of other cultural influences, e.g. Chinese, Indian, and Arabic elements amongst others. It is cosmopolitan, a rooted one, in the way such elements were recognised and reproduced in order to cater to its diverse and multicultural audience. The awareness of the presence of this audience was made possible by the already established networks and exposures of the interconnected global world reflected in the composition of the port city.

Portrayal of Malay cosmopolites in advertisements worked in two-way where these imageries of Malays can be regarded as the proprietor and portrayal of such cosmopolitan representation. As advertisement is suggestive in nature, it is observed as a portrayal derived from a specific context-location and periodwhere such suggestions were sourced, or partly reflected, from an actual and existing condition of urban Malays in port city. Advertisement informs, and it does so through recognising its audience has already equipped with the comprehension of products with which it tries to inform. 
By 1930s, Malayan entertainment industry encompassed a range of selections including commercial theatre such as bangsawan, music (live performance, radio, or gramophone), films, funfairs, and cabarets. At that time, urban entertainment enjoyed a wide acceptance with "a variety of nonindigenous cultural activities and commercial theatre" for its diverse urban population as well as the emergence of a new media culture from the "convergence of print, gramophone, radio, film and theatre to entertain multiethnic audience from different social and class backgrounds" (Tan Sooi Beng, 2013). Radio and cinema, for instance, as part of the new media were central in establishing the popular entertainment culture amongst the people through various programmes and shows including English, Malay, Chinese, and Tamil that reflected the diverse composition of audience during the era (Augustine \& Lochhead, 2015, p. 15).

The emergence of urban multi-ethnic population in Malaya gave birth to a new cultural and recreational activities in the form of Malay social and sports clubs including sports and indoor games such as billiards and card games (Roff, 1967) as well as a variety of music, drama, and staged plays (Tan Sooi Beng, 1993, p. 9). In her seminal work Bangsawan: A Social and Stylistic History of Malay Popular Opera, Tan Sooi Beng (1993) not only provides an in-depth analysis on the multi-dimensional feature of bangsawan as a form of commercial performance rather than a traditional Malay theatre, but also illustrates the landscape of entertainment industry in which bangsawan was one of the favourite pastime entertainments for urbanites.

Bangsawan features a cosmopolitan ideal through its eclectic and flexible characteristics, which captured the urban composition of port cities in Malaya. As Tan argues, bangsawan is a commercial performance in contrast with the claim that perceives it as a traditional Malay theatre in which its range of adaptations in its presentation, stories, and songs were dependent on the type of audience. As van der Putten (2010) noted,

Bangsawan troupe in the early twentieth century were able to adapt to the configuration of the audience and context of the event, playing Chinese stories to a predominantly Chinese audience, or even staging a Western story for an official British event. For these performances the language was Malay, and it may be surmised that the urban community was sufficiently proficient in the language to enjoy the simple stories with the jokes and songs. 
In late 1930s, Bangsawan was adopted into Malay films, popularised, and supported by renowned producer, the Shaw Brothers with most of its actors and actress coming from the same group of bangsawan performers (Barnard 2010). With the growing demand for entertainment such as shown by the success of bangsawan performances, devices like radio and gramophone made it possible for favourite songs and shows to be enjoyed in one's home. One of GC's labels, 'His Master's Voice' (HMV) or 'Chap Anjing' (Dog Label) was frequent advertisers of Malay songs in Warta Ahad, occasionally featuring popular bangsawan plays such as 'Puteri Gunung Ledang' and 'Laila Majnoon' as well as keronchong music. Incorporation of bangsawan into the recording scene, along with cheaper price of gramophones, helped to expand popular entertainment amongst Malays.

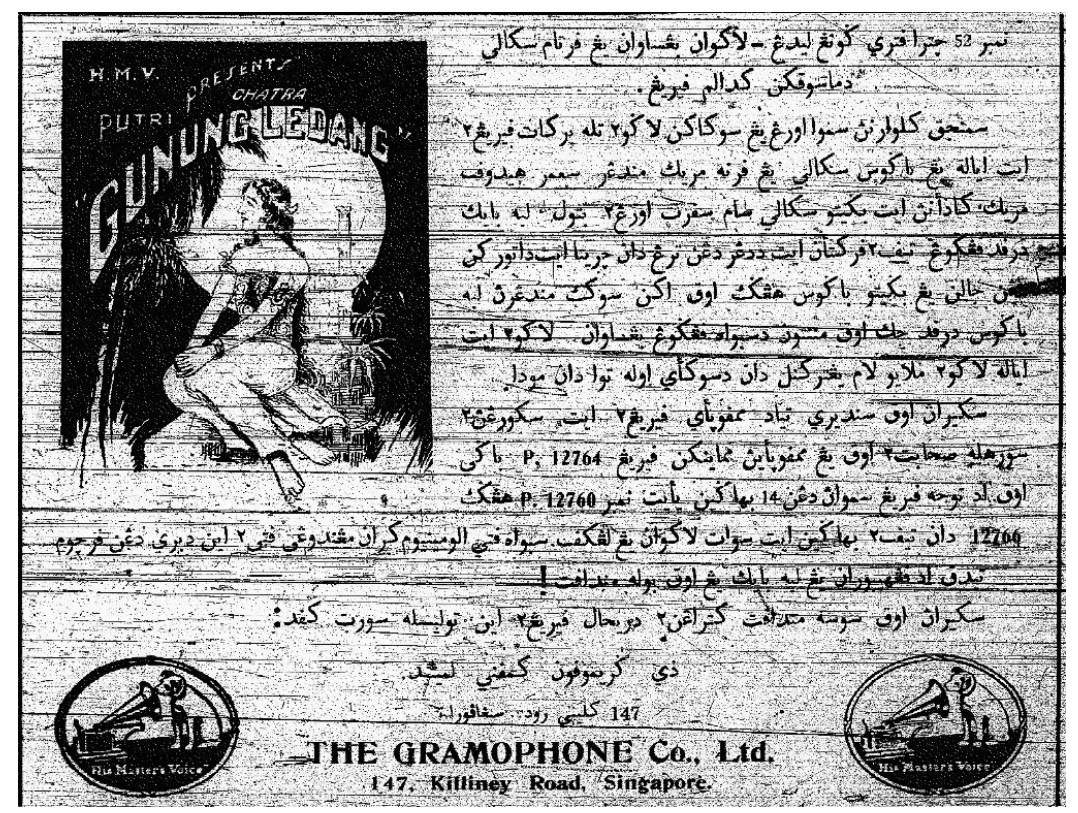

Figure 1: Puteri Gunung Ledang record, Warta Ahad, 16 June 1935

(Source: Perpustakaan Tun Sri Lanang, Universiti Kebangsaan Malaysia [UKM].) 


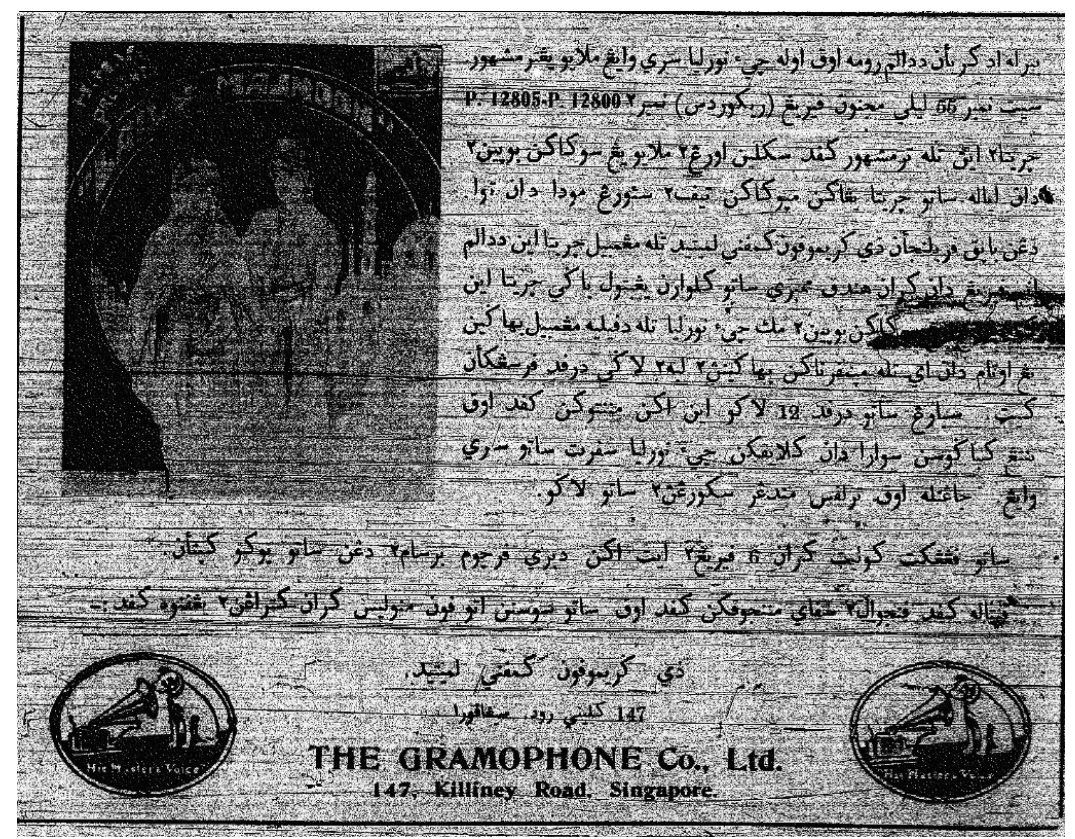

Figure 2: Laila Majnoon record, Warta Ahad, 14 July 1935

(Source: Perpustakaan Tun Sri Lanang, UKM.)

Another sought-after popular entertainment during that time was films. Cinemas in Malaya started to gain popularity as early as 1920s, mostly dominated by American films until early 1930s (Barnard, 2010). While it is difficult to gauge the popularity of cinema viewing amongst the Malays at the time, it is reasonable to say that these foreign films were appreciated, or at least known, by MalaysWarta Ahad allocated a section for film review, announcing new films currently show in local theatres. A case in point is one regular advertiser in Warta Ahad, the 'Lux Toilet Soap' that used an interesting approach to attract its Malay audience to buy its product. The growing films industry and popular culture in Malaya led to the incorporation of such entertainment into product advertising, such as in the form of collectibles. As shown in Figure 3, the brand gave free collectible photos of film celebrities in exchange of a certain, required amount of purchase of its products. Such advertising strategy would encourage bulk purchasing (but for a normal price per item) or a consistent purchasing until the buyer has met the required condition for the exchange. This would attract a percentage of the targeted audience to become regular buyers, thus ensuring a growing chain of consumption from its potential clients. 


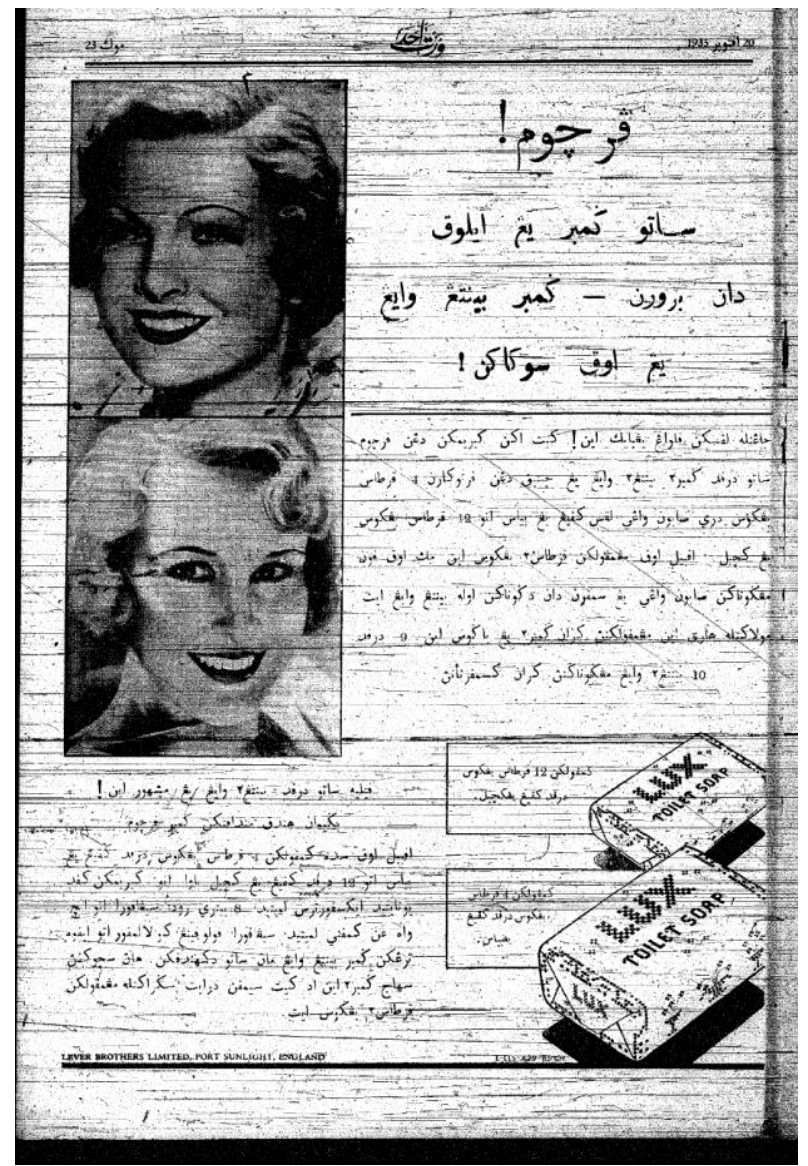

Figure 3: "Free! One fine and coloured photograph of popular actresses you admire!" [Percuma! Satu gambar yang elok dan berwarna-gambar bintang wayang yang awak sukakan!], Warta Ahad, 20 October 1935

(Source: Perpustakaan Tun Sri Lanang, UKM.)

The running of film celebrities as an attraction indicates the magnitude of influence that entertainment industry had on urban Malays. Portrayals of these celebrities, in a way, acted as an influence and a frame of reference for its audience on trending fashions and styles at that time. Such representation of these Western celebrities capable of altering and shaping the existing preferences according to the latest trend. More than a selling point, these celebrities were the representation of the notion of beauty in which it has great influence of trends including fashion, hairstyle, and self-representation of one's personality or identity. Such influence is depicted in Su Lin Lewis' (2009) analysis on the image of the "Modern Girl" embraced by women in port cities, especially the younger generations, in 1930s Penang. The "Modern Girl", as its name stands, is an 
embodiment of modern values within a woman in which ideas on freedom, liberation, and progress as well as how these prescriptions accentuate a woman's beauty and personality played a pivotal role in shaping the women's outlook. The advertisement reinforces its attraction by highlighting testimony saying the soap is used by "nine out of ten film celebrities" (Figure 3), which asserts a kind of imagination that one can be as beautiful and successful as these film stars by using the soap.

Advertisements in that period also emphasised recreational or leisure activities such as the consumption of beer and cigarette. While it is inconceivable for such advertisements to appear in present-day Malay newspapers, beer advertisements such as published in Majlis that specifically targeted and portrayed Malays were common back then. Tiger beer advertisements in Majlis, for instance, was portrayed to have positive effects on health and happiness. Advertisement showing Malay men and women, clearly depicted by their songkok and scarf respectively, holding cans of Tiger beer and accompanied by short captions, often with words such as kuat (strong), sihat (healthy), or ria (happy) (van der Putten, 2010). One particular advertisement, as noted by van der Putten (2010), shows the act of drinking beer as a pastime activity indicated by "a drawing of Malay men playing a game of what seems to be sepak raga, a pastime activity closely identified with Malays, while two others enjoy a beer in the foreground." The Tiger advertisement reflects the intentionality to incorporate a new form of recreational or pastime activity-external and foreign-into the Malay culture. It creates a new imagination of what Malay culture is or ought to be, and frequent depiction of such element would lead to the normalisation of such activity as part of Malay lifestyle, which implies a modernised and rather sophisticated character.

Apart from beer, another popular product with frequent and wide promotion in advertisements was cigarettes. In the case of Warta Ahad, cigarette advertisements had a prominent place in terms of marketing where cigarette advertisement appeared in every issue (from 1936 to 1938) and always took up the full-page, on the back cover of newspaper-indicating a huge marketing expenditure on this product. The placement and size of advertisement say something on the level of attention and profitability cigarette companies have on their potential clients, the Malays. Popular cigarette brands such as Craven A, State Express 555, and Gold Flake adopted similar approaches taken by Tiger beer through the incorporation of images of Malay men and women as well as portraying landscape that was familiar to them, e.g. cow cart and hut by the sea. Figures 4 and 5 are advertisements from the established cigarette brand, Craven A, portraying smoking cigarette as a habit that accompanies pastime activities 
such as hanging out or playing card games. Smoking was considered a supplementary activity that increased the excitement of pastime activities such as displayed by the caption in Figure 5 .

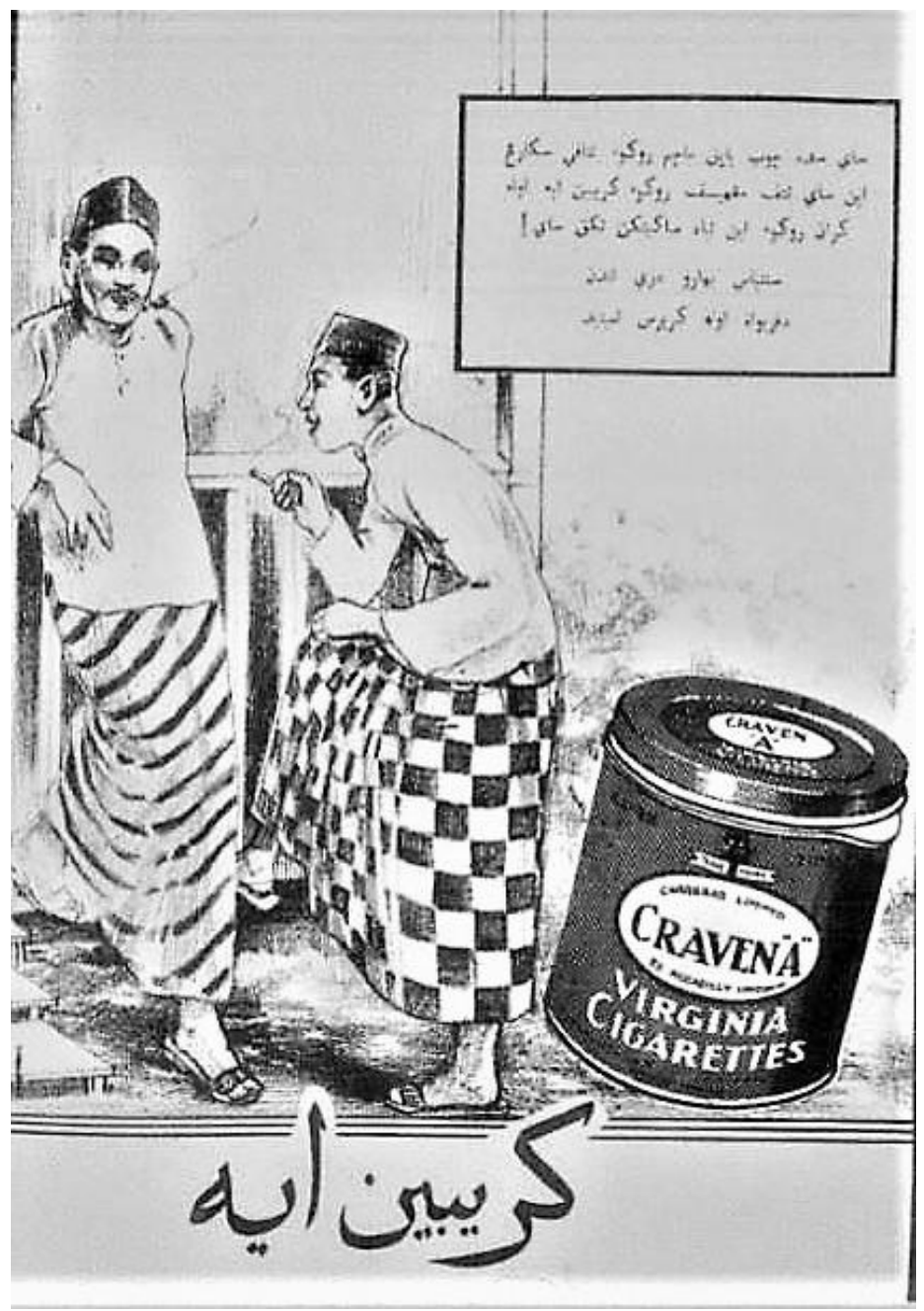

Figure 4: "I have smoke many cigarettes but now I stick with Craven A because it does not hurt my throat!" [Saya sudah cuba banyak macam rokok, tetapi sekarang ini saya tetap menghisap rokok Craven A oleh kerana rokok ini tiada menyakitkan tekak saya!], Warta Ahad, 5 July 1936

(Source: Perpustakaan Tun Sri Lanang, UKM.) 


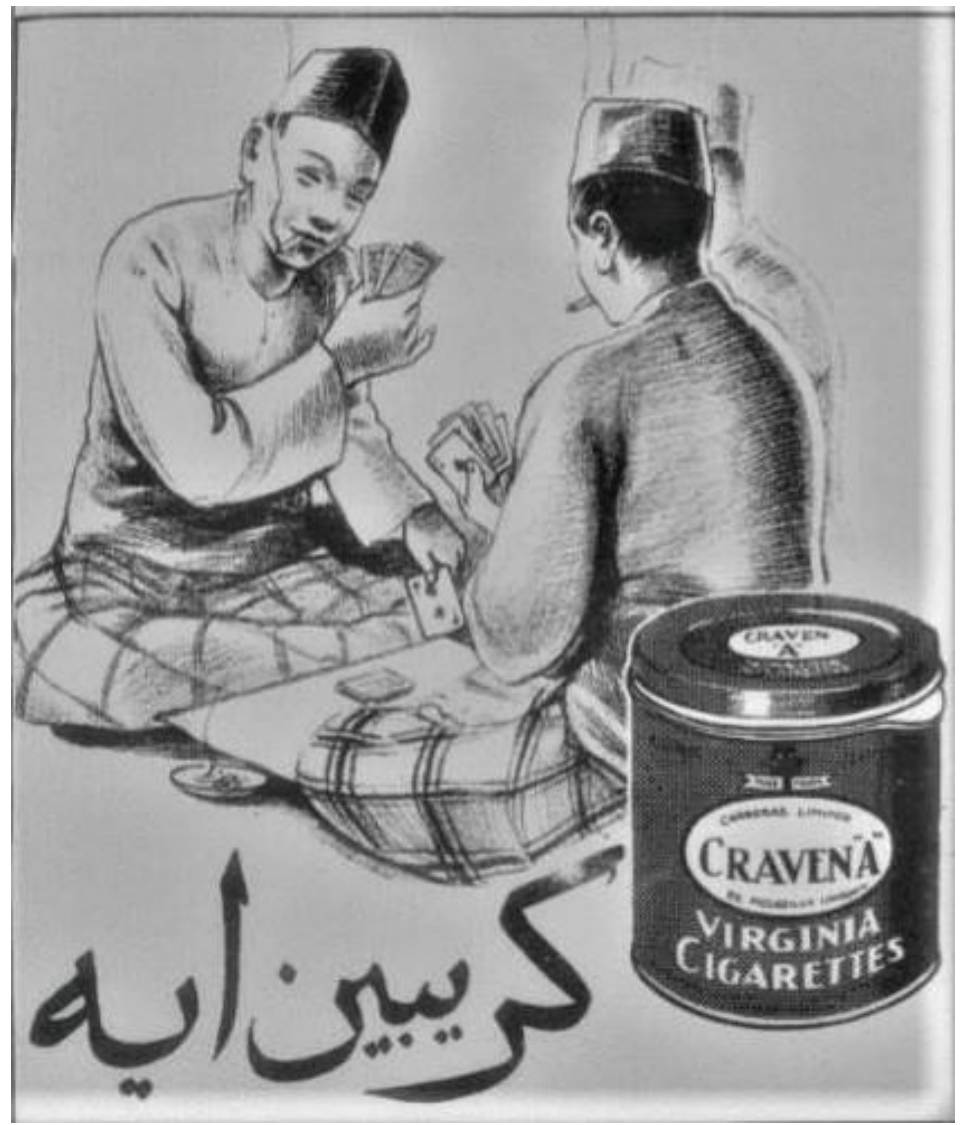

Figure 5: "Craven A cigarette adds the excitement to the game." [Rokok Craven A menambahkan lazat kepada permainan.], Warta Ahad, 10 May 1936

(Source: Perpustakaan Tun Sri Lanang, UKM.)

Another interesting characteristic of these cigarette advertisements is the portrayal of women imageries as an active promoter of the product rather than just a passive subject such as shown in Figures 6, 7, and 8. As noted by van der Putten (2010) in the context of Majlis, the editorial had "few qualms about courting controversy with Islam by placing one of the Tiger ads next to a picture of the Sulaimani Mosque in Klang", although the same editorial was cautious with the usage of words to avoid any sexual connotations related to women, thus preserving public morality. In these cigarette advertisements, depiction of women as smokers could be argued as a relatively new activity that was yet to be registered into the Malay norms, hence not considered a taboo or against public morality. Capitalisation of both genders portrays a disregard of domestic role in Malay society-where usually it is the male that indulged in recreational activities while the female would usually just chat with their peers-and the 
inclusion of both men and women into the constructed modern lifestyle where both were portrayed as equal in terms of leisure, consumptions, and entertainment.

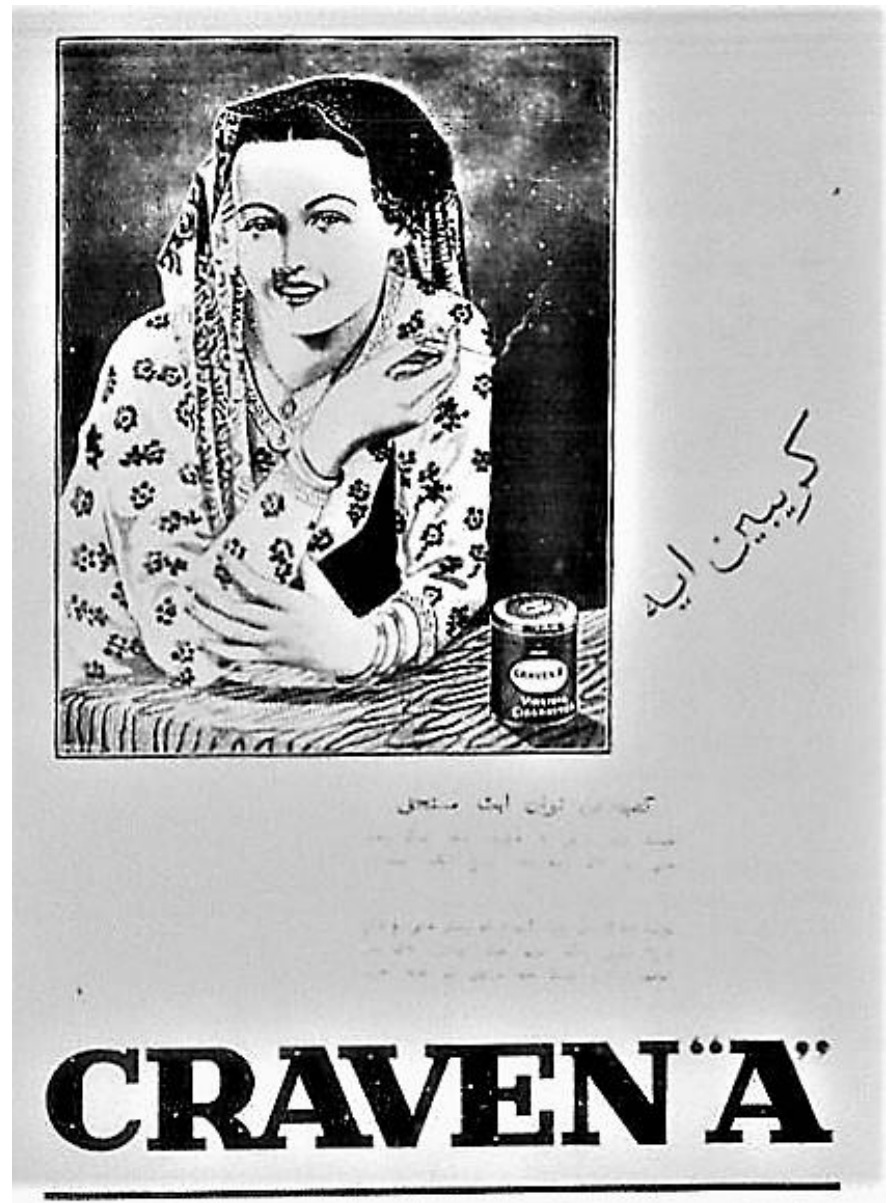

Figure 6: "Your health is important" [Kesihatan tuan itu mustahak], Warta Ahad, 6 February 1938

(Source: Perpustakaan Tun Sri Lanang, UKM.) 


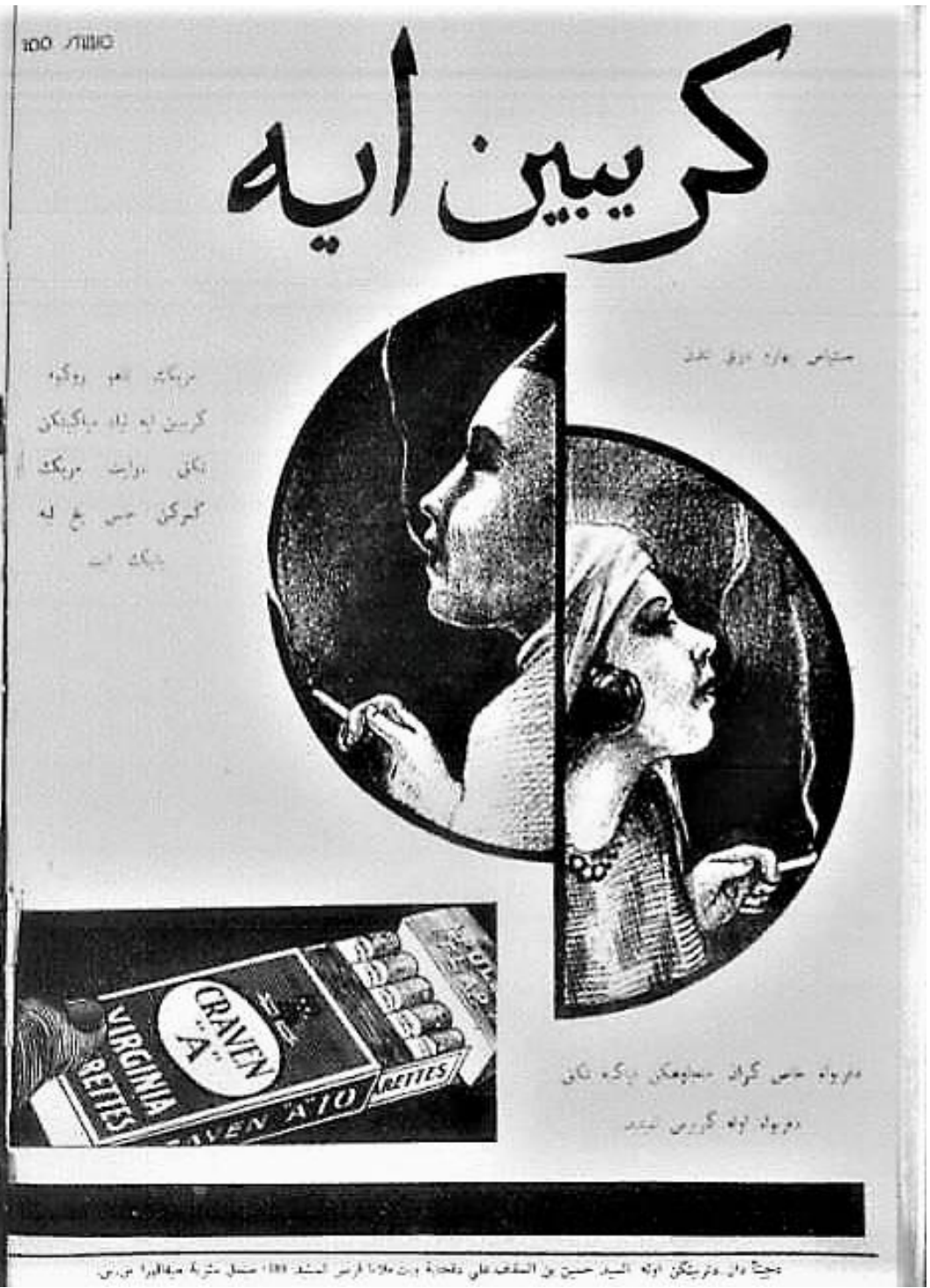

Figure 7: Craven A advertisement, Warta Ahad, 11 October 1936 (Source: Perpustakaan Tun Sri Lanang, UKM.) 


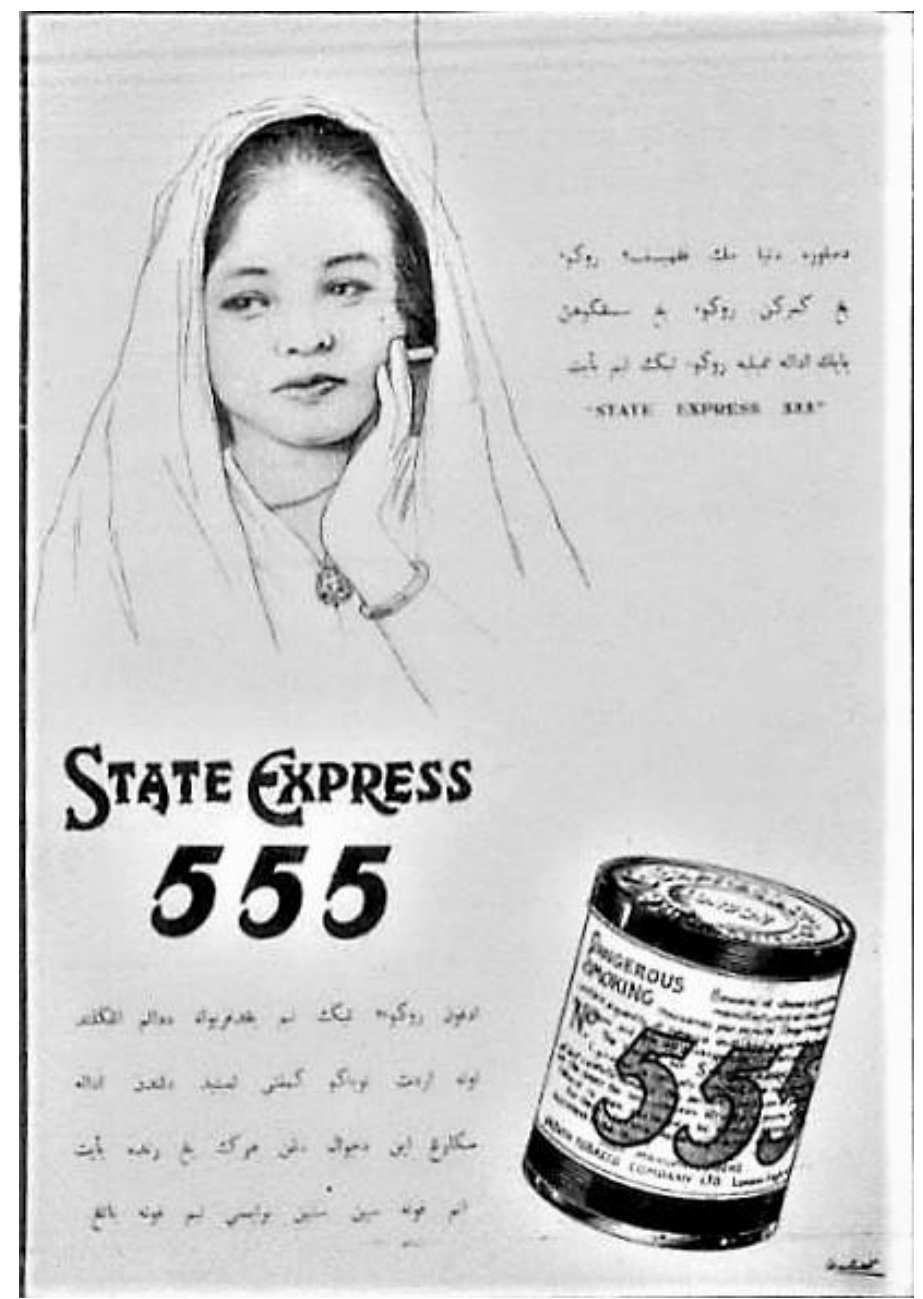

Figure 8: State Express 555 advertisement, Warta Ahad, 21 March 1937 (Source: Perpustakaan Tun Sri Lanang, UKM.)

Some advertisements such as the Lion cigarette in Majlis also held contests for its readers to write the best catchphrase for the product (van der Putten, 2010). Inclusion of its audience in a direct communication, through contests, invokes a sense of relatedness as fellow readers and consumers of that product as well as interconnectedness with the larger world where this international brand represents. Consumption of entertainment (gramophones, films, etc.) and leisure (beer, cigarette, etc.) in the media portrays a packaging of these elements as a modern lifestyle unique for urban populace, partly characterised by its mode of production particularly white-collar works. These advertisements not only suggest a type of consumption lifestyle but also represents the emergence of the 
concept of leisure, as we have observed through the many social clubs and recreational activities participated by Malays mentioned before, within the urban milieu during that time. They were underlined by an outlook that perceives urban, and to an extent town, residents as already being incorporated into the capitalist economic framework which presupposes waged labour with fixed job hours, six days a week. One bangsawan advertisement by Moonlight Opera, for instance, invited the public to its shows during the weekend after " 6 days of hard work/after 6 nights of unrest..." (Straits Echo [17 June 1933], quoted in Tan Sooi Beng [1993, p. 20]).

The promotion of this modern lifestyle that emphasised entertainment and leisure entails the normalisation of consumption in everyday life. We have observed, through van der Putten (2010), how beer drinking was normalised as a part of pastime activity within the Malay community in the advertisements. This is also true with smoking cigarette where constant exposure and portrayals of Malays smoking contributed to the normalisation of such consumption activity as a given amongst the community. Singapore and Penang, as two main port cities in Malaya, were the first to receive any new technology, goods and services, and latest trends-all which materialised in the form of modern lifestyle of 1930s. Malay cosmopolites, who commonly associated with this kind of lifestyle, were perceived critically by Malay intelligentsias who saw them as destructive to Malay cultural tradition

\section{Critique on Cosmopolitan Malays in Caricatures}

One of the features of Malayan newspapers in the early twentieth century was its function as a medium for 'concerned citizens' to express views, opinions, and interact with others through commentaries and letters to editor sections. Malay newspapers, in particular, displayed a distinct characteristic of being more of a "viewspaper" rather than news reporting where there was active participation from readers and editorials in commenting and discussing various issues especially pertaining to the Malay cause (Emmanuel, 2010). The Malay intelligentsias were wary of the deprived condition of Malays in urban areas due to them being unable to compete, economically, with other races. Their cautions and prejudices were often directed, without any reservation, towards the Chinese who was considered to possess great economic access and capability as well as favoured by the British. Others such as Abdul Rahim Kajai and Utusan Melayu (1939-1941) directed their critique internally, towards the Malayo-Muslim communities namely the Arab and Jawi Peranakans who have special status in Malay society. These two communities were considered by the Utusan as 
destructive towards the Malay community due to their special status contributed by economic superiority and religious authority that enabled them to exert influence over the larger Malay society.

It is important to note that while critique is a tool to advocate a certain ideological or principle, critique nevertheless also a form of reflection that depicts the condition or behaviour of its subject of critique. Thus, through the critique itself, we gain insights of the characteristics particularly pertaining to the lifestyle and outlook of Malay urban dwellers in 1930s. In the context of this paper, visuals such as caricatures in which the critiques are present posed as a realistic depiction of the lifestyle of Malay cosmopolites. While writings contain clear ideological dictions and bearings, caricatures depict a comprehensive albeit contradictory portrayal, in a sense that there are multiple approaches and dimensions in interpretation, especially caricatures that has more than one creator. Visuals also capture both the characteristics of their subject and the setting the live in, as well as reflecting the critics' comprehension and observation of their surroundings. This is especially true in Wak Ketok series published in Utusan Zaman where the character was created by two people: Ali Sanat (illustrator) and Abdul Rahim Kajai (writer). Although both of them have similar ideological leaning, yet they remained two distinct individuals with two different perspectives and approaches. Then, caricature as a tool for critique also portrays a micro-level interaction, especially pertaining to intra-ethnic contestation in which it acts as a medium for the formation of identity of that particular group (see Johnson [2006]). Through the Wak Ketok character, the Malay cosmopolites were portrayed as not having any (or small) affiliation towards 'authentic' Malay cultural tradition-whether through their lifestyle, clothing, or attitude and can be considered as having accustomed to the modern lifestyle influenced by foreign tradition (Razan Rosman \& Sarena Abdullah, 2018).

Figure 9 below is one of the examples of Wak Ketok's critique on Malay cosmopolites' excessive entertainment and extravagance lifestyle, negative qualities associated with Malay cosmopolites that persisted in each of its critique on the group. Figure below shows a scene of Wak Ketok dancing with a foreign lady in a cabaret club. There are three elements typical in Wak Ketok's column and critique. First, his chameleon-like figure, which is a trademark for the character, where he assumes various disguises-sometimes as an Englishman, sometimes as Arab or Jawi Peranakan, and other times as a Nusantara Malaycoupled with jobs or activities such as below. Secondly, despite his many disguises, what remains constant is his feature and attitude; a typical Malay (Nusantara) man. Lastly, these two elements were always portrayed to 
contradicting each other in a setting such as Figure 9. At first glance, we can see that Wak Ketok is blending well in the club, reflected in his proper attire for the occasion. However, his conspicuous Malay feature distinct him apart from the others - he is the shortest male, and also shorter than his dancing partner, a foreign lady. His 'Malayness' is immediately revealed when Wak Ketok is dancing where he becomes a nuisance to others in the club-depicted by the unhappy faces around him and his partner's uncomfortable face. The portrayal of this setting subscribed to Kajai's view that Malays would remain as Malays despite changing their appearance and lifestyle (Abdul Latiff Abu Bakar, 1984, p. 107).

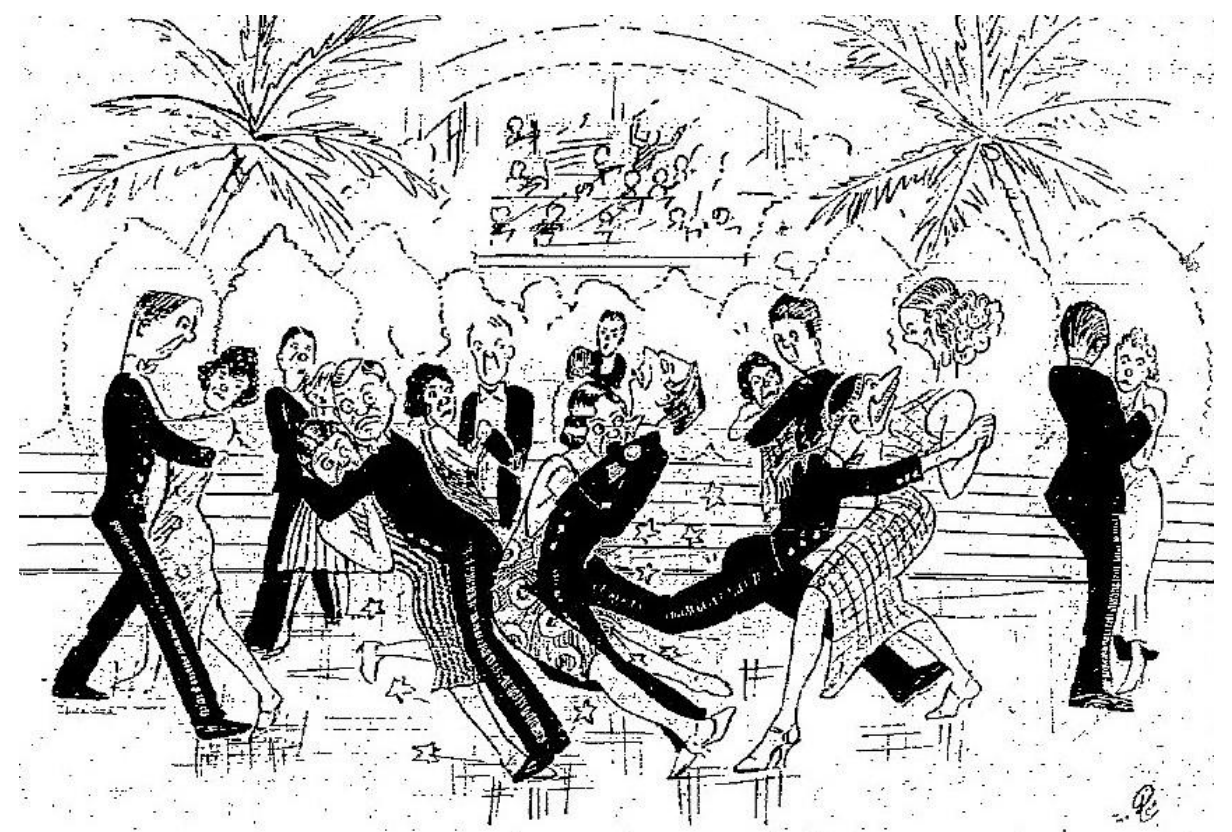

Figure 9: Wak Ketok dancing in a cabaret club, Utusan Zaman, 14 January 1940 (Source: Perpustakaan Tun Sri Lanang, UKM.)

This is not an isolated depiction of urban Malays influenced by the modern lifestyle. Throughout the Wak Ketok series, this group of Malay was often portrayed to immerse themselves in excessive entertainment activities, lavish lifestyle, and did not follow Malay traditional custom. On the one hand, such critique attempted to show that while these urban Malays can change their appearance and attitude by subscribing to a modern lifestyle, it would remain only as a façade, and his natural behaviour would be revealed once he speaks or acts because he could not fully grasp the habit and manner of such lifestyle. On 
the other hand, these imageries can be read as a suspicion towards modern lifestyle, which entails a subscription of other world outlooks that would result in the diverse affiliations to multiple identities. Portrayals of urban or cosmopolitan Malays in the series highlighted the 'un-rootedness' qualities signified by their appearances, attitudes, and lifestyle. The double consciousness, the many affiliations, shown by this group was considered as a barrier in the project to build a single and unified Malay identity, which hindered Malay solidarity (Razan Rosman \& Sarena Abdullah, 2018).

\section{Conclusion}

The emergence of a new segment of Malay urban dwellers, the cosmopolites, is found in the creation of ideal Malays in advertisements where it promulgated a type of lifestyle-along with an outlook-revolving around leisure and consumption. It was within this framework that we could see the changes amongst urban Malays in terms of changing the preference of mode of production (e.g. office jobs), their idea of success, masculinity, and femininity, as well as the diverging identities marked by the type of lifestyle they subscribed. The encouraging imageries of these advertisements, albeit indirectly, became a source of critique for 1930 Malay intelligentsias, particularly in Wak Ketok series, where it saw the modern lifestyle as further fragmenting the 'authentic' Malay identity. Narratives found in the stream of visual imageries in either depiction of advertisements or critiques in caricatures portray the cosmopolitan experience situated in the setting of port cities. The two type of depictions proposed by these imageries, the persuading and opposing, reflect a more comprehensive reading on the condition of urban Malays in port cities at that time. As such, one could discern the brand of cosmopolitanism professed by these segment of Malays by looking at the visual imageries that reflect the conditions of the time.

In contrast with the framework of plural society closely associated with the more rural Malay states, polyglot society in port cities provides a greater potential of developing agency amongst its members. Penang and Singapore as hubs for trade and commerce have various cultural enclaves that intersected in daily routines, different from other Malay states. By observing these visual imageries, it could be observed that this segment of Malays has already acquired a degree of cosmopolitan persona as reflected in their acquired taste and preference, primarily through consumption and leisure. Against the economic monopoly of the others and encroaching westernisation on their lifestyle, Malay intelligentsias residing in these two cities received first-hand experience of the impoverished economic and cultural traditions of Malays in urban centres. 


\section{Acknowledgements}

The authors would like to thank Universiti Sains Malaysia (USM) and USM's RU(I) Grant (1001/PSENI/816285) for the funding that enabled the authors to conduct this research. The authors would also like to thank Perpustakaan Tun Sri Lanang, Universiti Kebangsaan Malaysia for these various archival materials.

\section{References}

A. Samad Ismail. (1993). Memoir A. Samad Ismail di Singapura. Bangi: Penerbit UKM.

Abdul Latiff Abu Bakar. (1984). Abdul Rahim Kajai: Wartawan dan Sasterawan Melayu. Kuala Lumpur: Dewan Bahasa dan Pustaka.

Abdullah Abdul Kadir. (1838). Kisah pelayaran Abdullah. Singapore: Press of the American Mission.

Ahmat Adam. (1992). Sejarah dan Bibliografi Akhbar dan Majalah Melayu Abad Kesembilan Belas. Bangi: Penerbit UKM.

Augustine, P., \& Lochhead, J. (2015). Just for the Love of It: Popular Music in Penang, 1930s-1960s. Petaling Jaya: SIRD.

Barnard, T.P. (2010). Film Melayu: Nationalism, Modernity and Film in PreWorld War Two Malay Magazine. Journal of Southeast Asian Studies, 41(1), 47-70.

Emmanuel, M. (2010). Viewspapers: The Malay Press of the 1930s. Journal of Southeast Asian Studies, 41(1), 1-20.

Hamedi Mohd. Adnan. (2015). 100 Akhbar Melayu: Vol. 1. Kuala Lumpur: Institut Terjemahan \& Buku Malaysia.

Johnson, D. A. (2006). Wak Ketok Defends Melayu: Mediated Exchange and Identity Formation in Late 1930s Singapore, Comparativ, 16(3), 68-86.

Khoo Kay Kim. (1974). Malay society, 1874-1920s. Journal of Southeast Asian Studies, 5(2), 179-198.

Lewis, S. L. (2009). Cosmopolitanism and the Modern Girl: A Cross-Cultural Discourse in 1930s Penang. Modern Asian Studies, 43(6), 1385-1419.

Matera, M. \& Kent, S.K. (2017). The Global 1930s: The International Decade. London: Routledge.

Muliyadi Mahamood. (2004). The History of Malay Editorial Cartoons (1930s-1993). Kuala Lumpur: Utusan Publications \& Distributors Sdn Bhd.

Nik Ahmad Haji Nik Hassan. (1963). The Malay Press. Journal of the Malayan 
Branch of the Royal Asiatic Society, 36(1), 37-78.

Razan Rosman, \& Sarena Abdullah. (2018). Wak Ketok and the Quest for Malay Identity in 1930s Malaya. Journal of the Malaysian Branch of the Royal Asiatic Society, 91(2), 19-48.

Roff, W. (1961). Guide to Malay Periodicals, 1876-1941. Singapore: Eastern Universities Press.

Roff, W. (1967). The Origins of Malay Nationalism, London: Yale University Press. Sivachandralingam Sundara Raja. (2014). Laissez-Faire in The Malay Archipelago: A Western Concept? JATI-Journal of Southeast Asian Studies, 19(1), 41-53.

Storey, J. (2012). Cultural Theory and Popular Culture: An Introduction. UK: Pearson Education Limited.

Straits Echo. (1933, 17 June).

Tan Sooi Beng. (2013). 'His Master's Voice': Gramophone Music and Cosmopolitan Modernity in British Malaya in the 1930s and Early 1940s. Bijdragen tot de Taal-, Land-en Volkenkunde, 169(4), 457-494.

Tan Sooi Beng. (1993). Bangsawan: A Social and Stylistic History of Malay Popular Opera. Singapore: Oxford University Press.

Utusan Zaman. (1940, 14 January).

van der Putten, J. (2010). Negotiating the Great Depression: The Rise of Popular

Culture and Consumerism in Early-1930s Malaya. Journal of Southeast Asian Studies, 41(1), 21-45.

Warta Ahad. (1935, 16 June).

Warta Ahad. (1935, 14 July).

Warta Ahad. (1935, 20 October).

Warta Ahad. (1936, 5 July).

Warta Ahad. (1936, 10 May).

Warta Ahad. (1936, 11 October).

Warta Ahad. (1937, 21 March).

Warta Ahad. (1938, 6 February). 